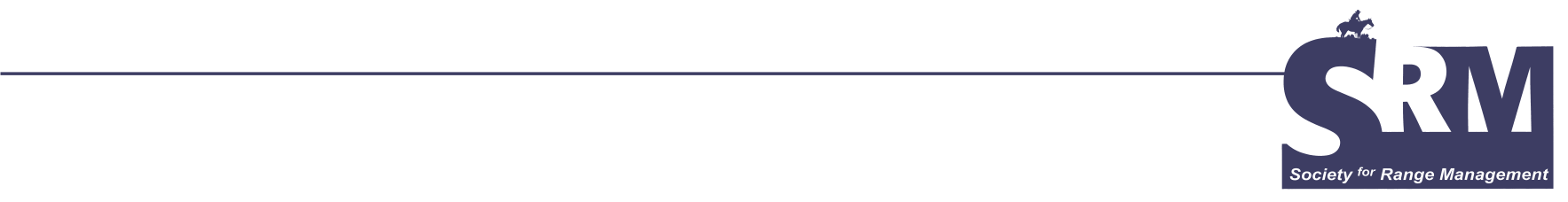

\title{
Sixth in a Series: Insight From SRM's Charter Members
}

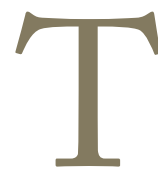
he Society for Range Management (SRM) History Committee has conducted interviews with many of the Society's Charter Members to capture their perspective of events leading to, and subsequent to, the formation of the American Society of Range Management in 1947-1948. Interviews from several of these individuals will be shared for today's SRM members to enjoy and learn from.

\section{SRM Charter Member - Charles Graham \\ Editor's Note: $A$ videotape and audiotape were made in July 2003 at Charles Graham's home by Sheila Barry of the California Section. The information was transcribed by Tom Bedell. Charles Graham lives at $390 \mathrm{~N}$ Winchester, Apt 13B, Santa Clara, CA 95050. Charles was known as "Charlie" and will be referred to that way here.}

When the American Society of Range Management (ASRM) was being organized in 1947-1948, Charlie was going to school on the GI Bill at University of California, Berkeley (UCB). He had been out of high school for 12 years at that time. In the 1930s, after high school, Charlie was in a Civilian Conservation Corps (CCC) camp. He took a civil service exam and was able to get into the US Forest Service doing vegetation mapping. He served in the US Army during the war, and when he got out, at Christmastime 1945, he decided to take advantage of the GI Bill and go to college. Because he had been working for the Forest Service before the war, forestry and range management were familiar, so he chose forestry school.

Charlie received both a BS and an MS from UCB. Before the war, he worked at the San Joaquin Experimental Range north of Fresno, California. Dr Harold H. Biswell was a Range Ecologist at the station at that time, and Charlie worked for him about 1.5 years. Dr Biswell had moved from Forest Service research to the faculty of the School of
Forestry at UCB in about 1947, and because Charlie had worked for and knew him at the San Joaquin Experimental Range, he became Charlie's advisor. Charlie took the range option as the degrees were in Forestry. Charlie remembers Dr A. W. Sampson, Dr Harold Heady, and Professor Kittredge on the faculty.

Dr Biswell was one of the organizers of the ASRM and a strong promoter of the Society. Charlie was encouraged to join and did so. Charlie does not recall that there were any Sections organized that early on, but when the California Section was organized, Charlie became active in it. Charlie did not attend the first ASRM annual meeting in Salt Lake City, Utah. He does recall going to Albuquerque, New Mexico, in 1953, for an annual meeting and to several California Section meetings.

Charlie stated that because he was working in research, the development of the Journal of Range Management aided greatly in publishing research results for a range-oriented audience. He felt it was one of the greatest values of the Society.

After he finished graduate school, he continued at the Forest and Range Experiment Station on a seeding project near Susanville, California, and worked with Dr Don Cornelius for several seasons. In 1953, Charlie became the Superintendent of the San Joaquin Experimental Range and remained there until 1965. At least two Section field days were held at that site during that time. He recalls going to the Rapid City, South Dakota, meeting and flying his plane there. Al Murphy was President of the California Section, and could not go; Charlie was asked to go to represent the Section.

In 1965, Charlie took a foreign assignment in Iran for 2 years. This didn't work out because he got bleeding ulcers, so he returned to the California Station. The war in Vietnam was in full swing, and research was needed evaluating chemical treatments on several species of woody plants, especially tropical ones. Charlie worked with Jay Bentley on this 
research. The research work was being conducted in Hawaii, Puerto Rico, Georgia, and Thailand. Charlie made several trips to all the locations except Thailand. The group also did some research on brush management near Glendora in southern California and Mt Shasta in northern California. Their primary research tool was a rotary sprayer mounted on a tall tripod. Vegetation was 15 or more feet tall. They set out over 700 plots testing various levels and formulations of picloram, 2,4-Dichlorophenoxyacetic acid (2,4-D), and 2,4,5-Trichlorophenoxyacetic acid (2,4,5-T).

As mentioned earlier, Charlie was in the California Section. He was on the Board of Directors for 1 term and then ran for Section President. He and Dr Harold Biswell were tied in the race, so a recount was made, and a ballot or two were found to be ineligible. Dr Biswell had won by 1 vote! Charlie says he never got active in the parent society.

Regarding his observations about the Society now and its direction, Charlie chuckled and wondered just how much progress is being made. It looks to him as if research is being published on the same subjects as it was years ago. This suggests to him that the same problems exist. Of course, Charlie says, he has been retired for 30 years and doesn't keep up as he used to. However, he does wonder just how much progress is being made, citing as one example, the continued focus on Bromus tectorum invasions.

Charlie says young people should join SRM because the relationships they will find with other professionals will be important and valuable. Their thinking will be stimulated. They will develop positions on subjects in which they are interested. Even though there will be disagreements, the experience will be very worthwhile.

\section{SRM Charter Member - W. A. "Bill" Hubbard} Editor's Note: This interview was conducted by Don Blumenaur, British Columbia Chapter, Pacific Northwest Section in 2002. Bill Hubbard lives at 2381 Tranquille Road, Kamloops, Canada BC V2B $3 N 6$.

In 1947-1948, I was working at the Dominion Research Experimental Station in Manyberries, Alberta, Canada. My line of work was in the short grass prairie, deciding how many cattle we could run on the range. Basically, it was range management concerning livestock, with the stock being Hereford cattle. My work involved finding out the carrying capacity of the range and what we could do to improve range conditions by rotational or continuous grazing, that type of thing.

We were approached - the superintendent, myself, and others - and asked how we would like to be members of a special society on range management. Before this time, all the publications on range management had gone through forestry and forestry journals. There was no separate journal of range management at that time. And so I, along with others, decided to join and become a charter member.

The Section was the Great Plains Section because we were in Alberta and worked on the short grass prairie. I was not able to attend the first annual meeting in Salt Lake City,
Utah, because of fiscal restraints and reluctance on the part of the Director General of Agriculture Canada at that time. I suppose I can say that my expectations in 1948 have been fulfilled. Sections have grown. Besides the 17 western states, there are 4 or 5 Canadian provinces that have become involved in the Society. At least we had a common place to meet and discuss the range across a wide variation in ecological types, all the way from Northwest Territories to Mexico.

In 1948, I attended university but was also employed, as I said, at Manyberries. I went to school for a couple of years, and then came back to work at Manyberries for a couple of years. I had received a BSA degree at the University of Saskatchewan in Forage Crops. I decided I needed more than that if I was going to stay with range management. I talked with Larry Stoddart, primary author of the range management text by Stoddart and Smith (STODDART, L. A., AND A. D. SMiTH. Range management. New York, NY: McGrawHill Book Co.; 1943). He suggested that I go to Utah State for a Master's degree, and I did, graduating in 1948. I came back to work for a while but received an opportunity to go to a museum in Victoria, BC, as a botanist. While there, I wrote Grasses of British Columbia (HubBARD, W. A. The grasses of British Columbia. Victoria, Canada: A. Sutton; 1969).

After some time, I thought I would like to get back into range management again. I had an opportunity at the research station at Kamloops, so in 1953 I came back. Tom Willis encouraged participation in the Society because he was a member, and he certainly gave me all the necessary encouragement.

I haven't held any offices in the Section or the parent society but have attended some of the annual meetings. In 1975, I took early retirement. I did go to the 50th anniversary meeting in South Dakota to see some of the old-timers and get reacquainted with people I had known for some years.

I think the SRM is on the right track, and I think anybody who is involved with livestock and rangelands can benefit from joining. I think we have had trouble over the years with the range and controlling grazing and controlling fires and one thing and another. I know you can talk with people who feel that cattle are part of the problem. I think, however, that the range management people and range ecologists are doing a great job in preserving the range, which is maybe not in its original condition but as close as possible to it, and keeping it in perpetuity for those coming up.

\section{SRM Charter Member - Glenn Mueller}

Editor's Note: On June 5, 2002, Chuck Jarecki interviewed Glenn Mueller. Glenn is an alert, 84-year-old, retired Forest Service employee, who keeps active and is up-to-speed on current land management issues. The interview was not tape-recorded. Glenn Mueller can be reached at PO Box 334, Libby, MT 59923-0334.

In 1947-1955, Glenn was employed by the Soil Conservation Service (SCS) at Malta, Montana, under the Land Utilization Program as the land manager of 10 grazing 
districts encompassing 1 million acres. A vast range-reseeding project was completed on the large acreages of abandoned croplands, mostly crested wheatgrass, that had been bought by the federal government. Efforts were being made to work out management systems for the lessees. At that time, there were no competing uses for the rangeland, and the grazing districts were the primary focus of attention.

Glenn recalls that he probably heard of the effort to form the American Society of Range Management through an SCS news publication and was an immediate supporter of the idea. At the time he joined, he does not recall that there were any Sections until several years later.

Glenn's first Section membership was in the Northern Great Plains when the Forest Service later employed him an assistant ranger at White Sulphur Springs, Montana. Later, he belonged to the International Mountain Section.

Glenn did not participate in the first meeting in Salt Lake City, Utah. However, he did attend the annual meeting in Great Falls, Montana.

Expectations in 1948 were to have an organization that would be of assistance in helping to keep current in the developing science and practice of sound range management. Those expectations have been met over the years. Although no longer taking the Journal, that publication was a major aid in keeping Glenn up-to-speed during his professional career. Glenn comments that he will continue to belong to SRM

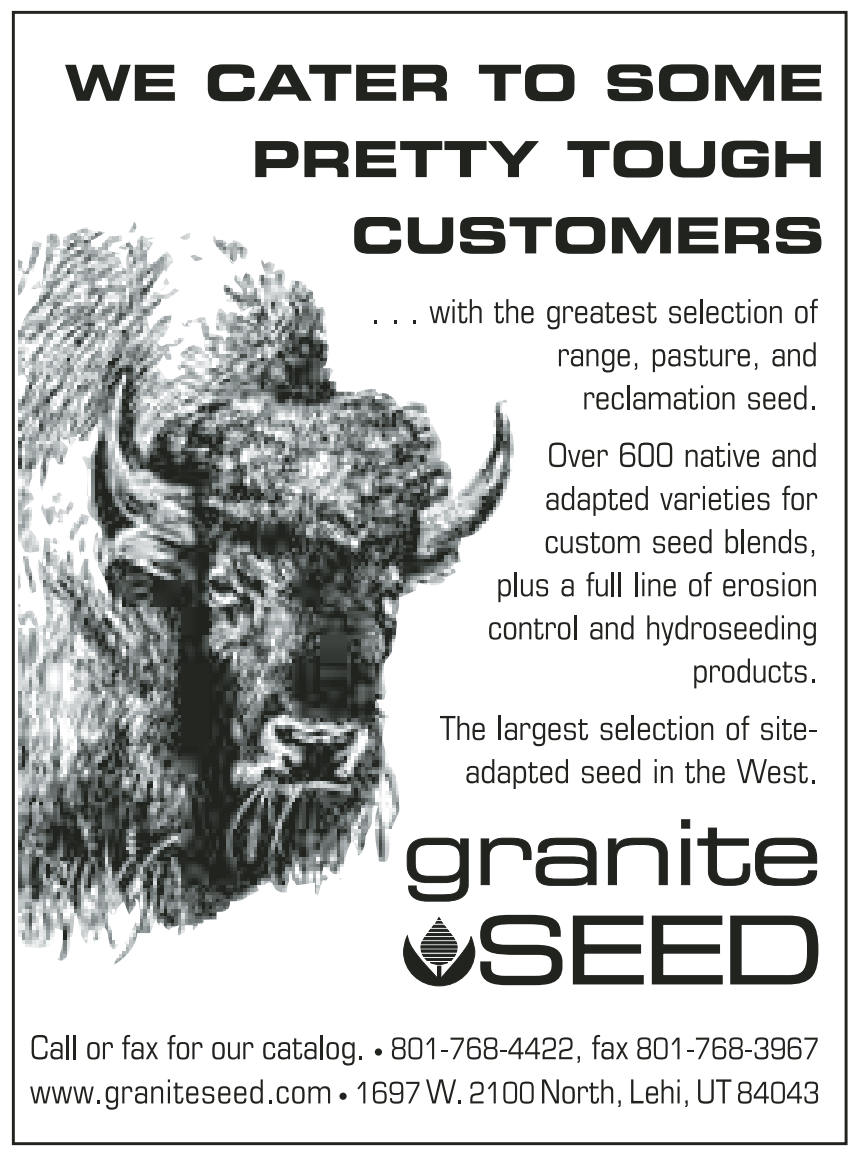

until he takes his last breath. Glenn also makes modest contributions to the SRM Endowment Fund.

Glenn emphasized that the SRM should never back down from supporting land management decisions that are based on sound science, even if that stance is not popular with certain segments of the population. Too often today, in this litigious society, land management policies are driven by public opinion that is too often influenced by "junk" science and not even by common sense.

Glenn was raised in the Lewistown, Montana, area. In his youth, he spent a lot of time hiking and camping in the surrounding mountains. During his years at the University of Montana, he was employed during the summers by the Lewis and Clark National Forest. In 1940, Glenn graduated from the University of Montana School of Forestry with a minor in Range Management. Mel Morris was his principle range professor. His first permanent job was with the SCS in west Texas as a range conservationist. He then transferred to Montana at Malta. Transfer to the Forest Service was made in 1956.

Following the job at White Sulphur Springs, Montana, Glenn became the Beartooth District Ranger on the Custer National Forest in 1957.

In 1962, Glenn was transferred to the Kootenai National Forest at Libby, Montana, where he served first as the Recreation and Lands Officer, and then on the Planning staff until retirement in 1978.

Glenn recalls that he was neither encouraged nor discouraged from belonging to SRM.

Following retirement from the Forest Service, Glenn served 2 terms in the Montana House of Representatives.

Glenn believes that the SRM would strengthen its position if the word "science" were to be incorporated into its name. The future of scientific land management is in question. Everyone today is an authority, and so much of this authority is based on emotion, not on hard facts and science. "It would be very difficult for me to work for the Forest Service today due to politics and failure to accomplish anything on the land."

SRM is on the right track. The organization needs to stand up and be counted as the voice of sound range management and policies. SRM needs to be managed as a business to be maintained on solid financial footing. Ranchers especially need to be made to feel welcome and be encouraged to participate in SRM activities.

A career in range management can be very rewarding for any young person to consider. As the number of competing uses for the range increases beyond the traditional use of mostly grazing, the challenges will become ever greater in balancing the needs of the different users while still maintaining the management of the land on the basis of science and common sense.

Tom Bedell is a member and former chairman of the SRM History Committee and a member of the Pacific Northwest Section living in Philomath, Oregon. 